\title{
AWARENESS OF RIGHT TO EDUCATION AMONG SECONDAY SCHOOL TEACHERS
}

\author{
Dr. (Mrs.) Navdeep Kaur \\ Assistant Professor, \\ Department of Education, \\ Guru Nanak Dev University, Amritsar. \\ email: negkaur@gmail.com
}

\begin{abstract}
Education is a human right and essential for realization of all other human rights. It is a basic right which helps the individual to live with human dignity the right to education is a fundamental human rights. Every individual, irrespective of race, gender, nationality, ethnic or social origin, religion or political preference, age or disability, is entitled to a free elementary education. Hence the present study has attempted to find out awareness of right to education among secondary school teachers. The sample of 200 secondary school teachers was taken. A self made questionnaire comprising 34 multiple choice items was used by the investigator. It was found that both Government and Private secondary teachers have equal information regarding RTE, whereas Male school teachers are more aware of RTE than Female secondary school teachers
\end{abstract}

Education is the foundation stone of national development. No nation can develops without education. The function of education is to accelerate the progress and development of nation. Education is the only means which brings about national integration. Educational achievement of a nation is also an indicator of national pride.

During the pre-british Indian the indigenous secondary education was imparted in Pathshalas, Gurukuls, Gurudwaras and other religious organization. Education was banned for women and for scheduled classes and poor people. After sometimes Christian missionaries and East Indian Company established a few schools with the purpose of spreading Christianity in India. The first organized step to established planned primary schools of four years duration in India was established when Macaulay presented his famous minutes in 1835 with a view to popularize English education. In 1854 Wood's Dispatch laid stress on imparting education atleast upto the primary level to the Indians.

Later many commissions and committees were set up like India Education Commission 1882, Government resolution on education policy 1904, Gopal Krishan Gokhale's Resolution 1911,Hartog committee 1929, Wardha Scheme 1938 and Sargent report 1944. All of them laid stress on free \& compulsory primary education. After independence India adopted Article-45 directive principle of state policy laid down in Indian Constitution. The Article says, "The state shall endeavour to provide within a period of ten years from the commencement of the constitution free \& compulsory education for all children untill they complete the age 6 to 14 years."

Kothari Commission (1964-66) recommended qualitative improvement for the purpose of science education, work experience, vocalization of education and development of social, moral and spiritual values, improvement in methods of teaching curriculum, teacher training etc. were recommended. National Policy on Education (1986) emphasized on two aspects. One on the universal enrollment and universal retention of children upto 14 years of age and another on the substantial improvement in teaching quality of education.

In order to improve the education of school, Operation, Blackboard was introduced by National Policy on Education. The programme of action (1986) was laid down," the purpose of Operation Blackboard is to ensure provision of minimum essential facilities in secondary schools, material facilities as learning equipment, use of blackboard implies that there is an urgency in this programme.

In India, the desire for compulsory education figured in the writing and speeches of our leader before independence. But for national development and national integration, creation of good citizens, preparation for life, development of character, development of individuality, adaptation to environment and making man civilized. India just implemented the "Right to Education" on $27^{\text {rd }}$ August (Thursday), 2009 by $86^{\text {th }}$ Constitutional amendent. It says, " the state shall provide free and compulsory education to all children the age of 6 to 14 years in such manner as the state may, by law, determine."

\section{Council for Innovative Research}

Peer Review Research Publishing System

Journal: Journal of Social Sciences Research

Vol. 6, No. 2

Jssreditor.cir@gmail.com

www.jssronline.com

$1004 \mid \mathrm{P}$ a g e

De ce mber 27,2014 
Today education is considered an important public function and the state is seen as the chief provider of education through the allocation of substantial Budgetry resources and regulating the provision of education. The pre-eminent role of the state in fulfilling the Right To Education is enshrined in 1966 International Covenant on Economic, Social and Cultural rights. With regards to realizing the Right to Education the World Declaration on 'Education for All' states that "partnerships between government and non-government organizational, the private sector, local communities, religious groups, and families are necessary."

The realization of Right to Education on a national level may be achieved through compulsory education or more specifically free and compulsory primary education as stated in both the Universal Declaration of Human Rights and the International Covenant on Economic, Social and Cultural Rights. So as India is first to made education compulsory and free for all. Formal Education is given to everybody without any discrimination of sex, caste, creed and colour.

Education is the powerful tool. which accelerates the process of national growth and development. Moreover, economically and socially marginalized adults and children can left themselves out of miseries of darkness and participate fully as variable assets for their nation only with the help of education.

Thus, education is a key towards a successful life. Keeping in view the importance of education, the secondary education in India has been made compulsory through $86^{\text {th }}$ constitutional amendment. Moreover Right to Education has declared as fundamental right by this amendment under Article-emerge as a global leader in achieving the millennium development goal of ensuring that all children complete their secondary education by 2015 as set by UNESCO.

The secondary stake holders for providing education are the parents and social authorities and both these entities have to be active: parents, by sending education is supported, thus, it is important that teacher should be aware of Right to Education. If teacher are well aware of Right to Education then only he/she can make the students to enjoy its benefits and motivate them to enroll in education. Moreover, if the teacher is fully awakened about the Right Education only then he/she will not dare to exploit the child.

So, the present study was undertaken with a purpose to probe into the awareness of secondary school teacher towards Right to Education.

\section{STATEMENT OF THE PROBLEM}

\section{AWARENESS OF RIGHT TO EDUCATION AMONG SECONDAY SCHOOL TEACHERS}

\section{OBJECTIVES}

1. To study the awareness about Right to education among secondary school teachers.

2. To compare the awareness about Right to Education with respect to type of schools.

3. To compare the awareness about Right to Education with respect to locale.

4. To compare the awareness about Right to Education with respect to gender.

\section{HYPOTHESES}

1. There is no significant differences in awareness about Right to Education with respect to type of schools.

2. There is no significant difference in awareness about Right to Education with respect to locale.

3. There is no significant difference in awareness about Right to Education with respect to gender.

\section{METHOD AND PROCEDURE}

DESIGN OF THE STUDY

The present study falls under the category of descriptive research.

\section{SAMPLE}

A sample of 200 secondary school teachers of Government and Private schools was involved in the present study. A random and purposive sampling technique was used for the purpose of selection of data.

\section{TOOLS}

In order to survey the Right to Education among secondary school teachers a self-constructed questionnaire i.e. 'Right to Education Awareness Test; was prepared and used for colleting the relevant date.

\section{STATISTICAL TECHNIQUES USED :-}

Descriptive Statistics :- Mean and Standard Deviation were used to analysed the data.

Inferential Statistics :- 't' test was applied to compare the results obtained through descriptive statistics. 


\section{HYPOTHESIS :1}

I.Government and Private Secondary School Teacher do not differ significantly regarding their awareness of Right to Education.

In order to test the Hypothesis-1, data was obtained with the help of questionnaire. The hypothesis was tested by calculating mean and standard deviation. The hypothesis was furthered examined by applying 't' test. The result of analysis is being shown in Table 4.2 .

Table 1

MEAN, STANDARD DEVIATION AND 't' VALUE OF GOVERNMENT AND PRIVATE SECONDARY SCHOOL TEACHERS ON AWARENESS SCORE OF RIGHT TO EDUCATION

\begin{tabular}{|c|c|c|c|c|c|}
\hline Variable & $\mathbf{N}$ & Mean & S.D & 't' & Interpretation \\
\hline Government & 100 & 14.98 & 4.59 & & \multirow{2}{*}{ Not Significant } \\
\hline Private. & 100 & 14.63 & 4.590 & .541 & . \\
\hline
\end{tabular}

A careful glance at the Table 1 Clearly reveals that obtained ;t' values 0.541 is insignificant, which indicates that Government and Private Secondary School Teachers do not differ significantly regarding their awareness of Right to Education Act. But a comparative study of means of scores of awareness of both the groups are suggestive of the fact that both are moderately aware of the Right to Education Act.

This moderate Awareness scores be due to fact that Newspaper, T.V. Internet and Magazines etc are easily available at work place as well as at home.

Hence Hypothesis-1, 'Government and Private Secondary School Teacher do not differ significantly regarding their awareness of Right to Education' stands accepted.

\section{HYPOTHESIS-2}

II. Rural and Urban Secondary School Teacher do not differ significantly regarding their awareness of Right to Education.

The Hypothesis was tested by calculating mean and standard deviation. The hypothesis was further examined by applying ' $t$ ' test. The result of the analysis is being shown in Table 2.

Table 2

MEAN, STANDARD DEVIATION AND 't' VALUE OF RURAL AND URBAN TEACHERS ON AWARENESS SCORE OF RIGHT TO EDUCATION

\begin{tabular}{|c|c|c|c|c|c|}
\hline Variables & $\mathbf{N}$ & Mean & S.D & 't' & Interpretation \\
\cline { 1 - 4 } Rural & 100 & 14.40 & 4.628 & \multirow{2}{*}{1.069} & $\begin{array}{c}\text { Not } \\
\text { Significant }\end{array}$ \\
\hline Urban & 100 & 15.15 & 4.500 & & \\
\hline
\end{tabular}

Table 2 reveals that the value of ' $t$ ' is 1.069 which is less than table value. The magnitude value of ' $t$ ' is 1.069 which is not significant.

However, comparative study of mean scores of Urban Secondary School Teachers (15.15) are more regarding Right to Education Act as compared to teachers of Rural Secondary School Teachers (14.40). This implies that teachers of Secondary Schools in Urban area are more aware regarding Right to Education Act as compare to teacher of Rural area. In Urban areas, more facilities are available for teacher such as Computer, Internet, Journals, Magazines and have to access to well-equipped libraries. Due to competition among teachers they have to keep their knowledge up to date. On the other hand rural teachers have less access to such facilities.

Hence, Hypothesis-2, Rural and Urban Secondary School Teacher do not differ significant regarding their awareness of Right to Education stands accepted.

\section{HYPOTHESIS-3}

Male and Female Secondary School Teachers do not differ significantly with respect to their awareness of Right to Education.

In order to test Hypothesis-3, data was obtained with the help of questionnaire. In it Mean, Standard Deviation was calculated. The hypothesis examined by applying 't' test. The result of analysis is being shown in Table 3 . 
Table 3

MEAN,STANDARD DEVIATION AND ' $t$ ' VALUE OF MALE AND FEMALE SECONDARY SCHOOL TEACHERS ON AWARENESS SCORES OF RIGHT TO EDUCATION

\begin{tabular}{|c|c|c|c|c|c|}
\hline Variable & $\mathbf{N}$ & Mean & S.D & ' $\mathbf{t}$ ' & Interpretation \\
\cline { 1 - 4 } MALE & 100 & 16.07 & 3.825 & & \multirow{2}{*}{4.068} \\
\cline { 1 - 3 } FEMALE & 100 & 15.15 & 4.500 & Significant \\
\hline
\end{tabular}

An examination of the Table 3 reveals that significant differences exist in the mean scores of Male and Female Secondary School Teachers on awareness scores which is evidence from ' $t$ ' value of magnitude 4.068.

Further, a comparative study of mean awareness scores of Male and Female Secondary School Teachers reveals that Males are slightly more aware of Female because Male teachers are active and intensive reader of Newspaper, Magazines and get more time to listen News etc. They have much knowledge about the latest information. On the other hand, Female secondary teachers due to responsibility family and other work do not have time to explore the latest information, so they are less aware. From above discussion our Hypothesis stands accepted.

Hence, Hypothesis-3, 'Male and Female Secondary School Teachers differ significantly with respect to their awareness of Right to Education' stands accepted.

\section{FINDINGS OF THE STUDY}

1. Government and Private Secondary schools do not differ significantly $(t=541)$ in their awareness of Right to Education. Thus, it is concluded that both government and Private Secondary teachers have equal information Right to Education Act.

2. Urban and Rural Secondary teachers do not differ significantly in their Awareness of Right to Education. Thus, it is concluded that urban and rural secondary teachers have equal level of information regarding Right to Education.

3. Male and female Secondary school teachers differ significantly in their awareness of Right to Education Act $(\mathrm{t}=$ 4.068). Mean score of Male teachers (16.07) is higher as compared to Female teachers (13.54). Therefore, it is concluded that Male secondary school teachers are more aware of Right to Education Act than Female Secondary teachers.

\section{CONCLUSION}

The present study is of great importance in the present time because its findings are totally relevant in the modern period. The awareness of Right to Education among secondary school teacher is of immense important for the welfare of the society as well as nation at large. Different commissions, committees, government and non-governmental agencies have supported the importance of Right to Education.

1. Knowledge of Right to Education Act, to secondary school teachers can help them to strengthen the application of Right of Education Act.

2. As it was found in the present study that rural secondary school teachers are not much aware of Right to Education Act. Thus they can engaged in In-service programs such as seminar, tea-time courses, refresher courses on Right to Education Act.

3. Right to Education Act can be initiated as a part of Teacher Training Programs.

\section{BIBLIOGRAPHY}

1. Achary, A.A. (1988). Compulsory Primary Education in Andhra Pradesh. A Police Analysis, as Quoted in Fourth Survey of Research in Education by M.B.Buch, (NCERT), Delhi, 11, 1260.

2. Aggarwal, J.C. (2010). Recent Development and Trends in Education, Delhi Shipra Publication.

3. Ajit Mondal, Dr. Jayanta Mete. (2009). Right to Education, New Delhi A.P.H. Publishing Corporation.

4. Bhargava, S.M.(1988). A Study of the growth of educational facilities and enrollment at the elementary stage in India, as quoted in Fifth Survey of Educational Research by M.B. Buch (NCERT) Delhi, 11, 1133.

5. Birdi, B. (1988). A Study of growth \& development of the primary education in Punjab From 1947 to 1987 , as quoted in Fifth Survey of Educational Research by M.B. Buch (NCERT), Delhi, 11, 1134.

6. Das, K.K. (1974).Evolution of the System of Elementary Education in Orrisa, as quoted in First Survey of Research. In Education by M.B. (NCERT), Delhi, 56.

7. Das, R.C. (1983).A Comparative Study of Educational wastage in urban \& rural areas, as quoted in Fourth Survey of Research in Education by M.B. Buch (NCERT), Delhi, 11, 1263. 


\section{ISSN 2321-1091}

8. Das, R.C. (1988).Administrations of Elementary Education in relation to the program of Universalization, as quoted in Fourth Survey of Research in Education by M.B. Buch (NCERT), Delhi, II, 1264.

9. Kaur, Parminder.(2004). A Study of Political awareness among secondary school teacher. Unpublished M.Ed Dissertation, Amritsar Guru Nanak Dev University.

10. Kansra R, (2011). A Study of Awareness of Right to Education Among Elementary School Teachers Unpublished M.Ed, Dissertation, Amritsar Guru Nanak Dev University.

11. Parimoo, (1974). A Critical Study of the Educational Conditions prevalent in Indian (1526 A.D. to 1707 A.D.) as quoted in First Survey of Research in Education by M.B., Buch (NCERT), Delhi, 69.

12. Rampal, A(2007).A Comparative Study of Human Rights Education awareness among higher school students of ICSE and CBSE, unpublished M.Ed. Dissertation. Amritsar, Guru Nanak Dev, University.

13. Rawther, S.H.Y (1988). A Comparative Study of the aims of Education at the Primary and Secondary levels as perceived by different sections of the society in kerala, as quoted in fifth Survey of Education Research by M.B. Buch, (NCERT) Delhi, 1, 277.

14. Reddy, G.S. (2011).Right to Education Act Bumpy Road Ahead, EDUTRACK, 10, 5.

15. Education \& legal Awareness, (2009). A weekly journals of Higher Education, University News, 47, 34, $24-30$.

16. http://www.education.nic.in

17. http://www.education.nic.in/secondary.htm

18. http://www.googlesearch.superemecourtviewverdic

19. http://www.indg.in/secondary-education/policies

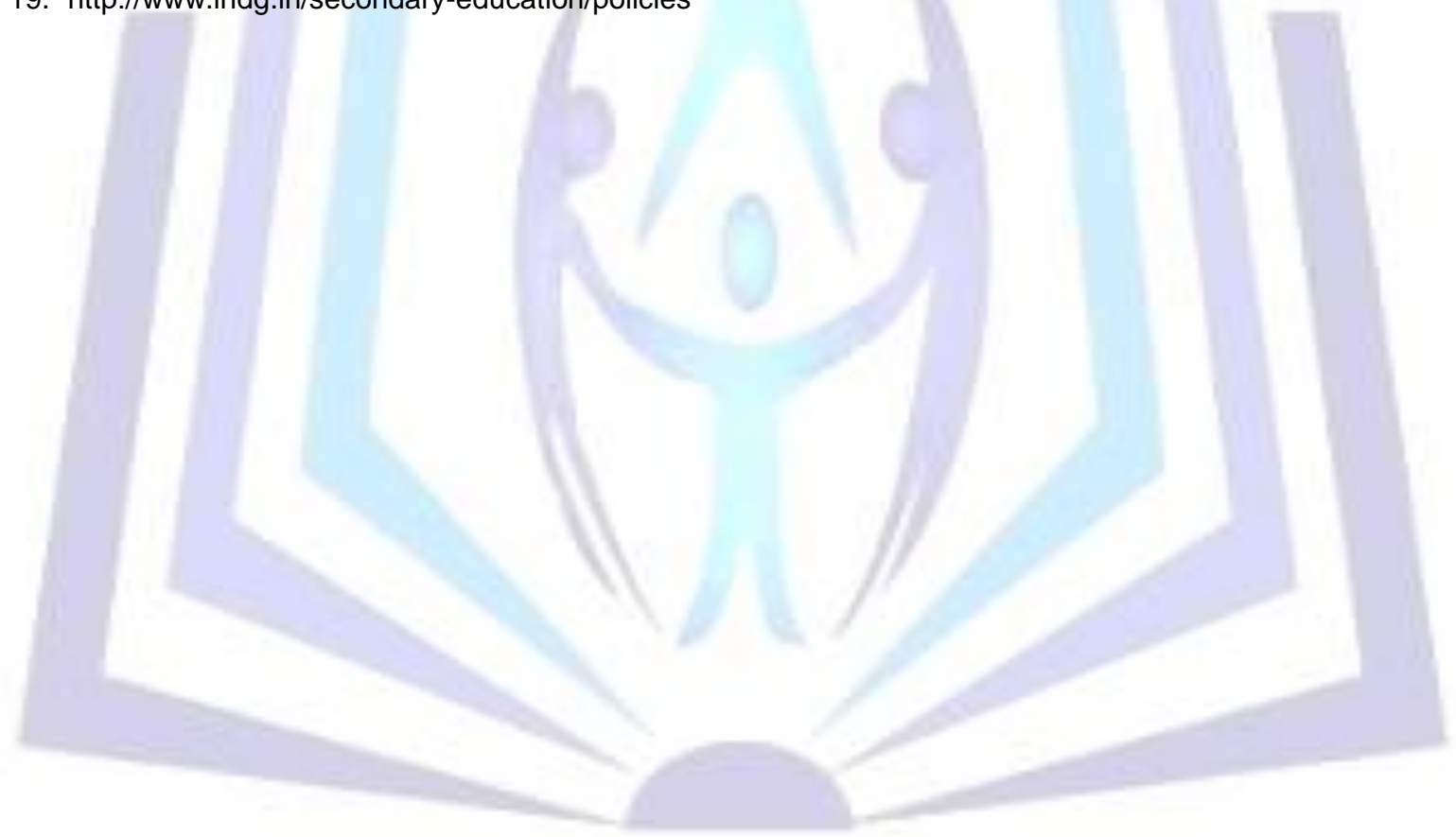

